\title{
Vitamin D plasma concentrations in pregnant women and their preterm newborns
}

Milene Saori Kassai ${ }^{1}$, Fernanda Ramirez Cafeo ${ }^{2}$, Fernando Alves Affonso-Kaufman ${ }^{2}$, Fabíola Isabel Suano-Souza ${ }^{1,2^{*}}$ (D) and Roseli Oselka Saccardo Sarni ${ }^{1}$

\begin{abstract}
Background: Vitamin D deficiency is a global public health issue. More than half of pregnant women are affected by vitamin $D$ insufficiency/deficiency. Studies suggest an association between low vitamin D concentrations during pregnancy with intrauterine growth restriction and prematurity. This study aimed to describe the concentrations of 25(OH)D (25-hydroxyvitamin D) of mothers who delivered preterm newborns compared to women with full-term pregnancy deliveries, as well as to relate $25(\mathrm{OH}) \mathrm{D}$ blood concentrations of mothers with those of their newborns.

Method: This cross-sectional study was conducted with 66 mothers who had given birth to preterm babies and their preterm newborns (PTNB, $<32$ weeks), and 92 women who had given birth at the full-term of their pregnancy and their newborns (FTNB). Data were collected on the characteristics of mothers (gestational age, diseases, and habits) and newborns (anthropometry and adequacy for gestational age). Ten milliliters of blood were drawn from the mothers and the umbilical cord of newborns at birth to identify the $25(\mathrm{OH}) \mathrm{D}$, parathyroid hormone, calcium, phosphorus, and alkaline phosphatase concentrations.

Results: Mothers in the PTNB group had significantly lower mean 25(OH)D blood levels $(21.7 \pm 10.8 \mathrm{ng} / \mathrm{mL}$ vs. 26.2 $\pm 9.8 \mathrm{ng} / \mathrm{mL} ; p=0.011$ ) and were three times more likely to have insufficiency when compared to mothers in the FTNB group $(\mathrm{OR}=2.993 ; 95 \% \mathrm{Cl} 1.02-8.74)$. Newborns in the PTNB group also had lower 25(OH)D concentrations compared to FTNB group $(25.9 \pm 13.9 \mathrm{ng} / \mathrm{dL}$ vs. $31.9 \pm 12.3 \mathrm{ng} / \mathrm{dL} ; p=0.009)$. There was a directly proportional correlation between mother and newborn umbilical cord 25(OH)D concentrations in PTNB $(r=0.596 ; p<0.001)$ and FTNB $(r=0.765 ; p<0.001)$.

Conclusion: Mothers who delivered preterm babies and their preterm newborns had lower 25(OH)D concentrations compared to women who had given birth at the full-term of their pregnancy. In both groups, 25(OH)D concentrations of the mothers correlated directly with those of the newborns, and this correlation was higher in the full-term birth group. Nevertheless, the recommended universal vitamin D supplementation in pregnant women to curb the risk of preterm birth is still incipient. More studies are required to clarify the particularities of vitamin D metabolism further and define the adequate $25(\mathrm{OH}) \mathrm{D}$ concentrations throughout pregnancy.
\end{abstract}

Keywords: Vitamin D, Newborns, Pregnancy, Umbilical cord

\footnotetext{
* Correspondence: fsuano@gmail.com

'Department of Pediatrics, Faculdade de Medicina do ABC, Avenida Lauro

Gomes, 2000. Vila Sacadura Cabral, Santo André, São Paulo 09060-870, Brazil

²Department of Pediatrics, Universidade Federal de São Paulo - Escola

Paulista de Medicina, Rua Botucatu, 898, Vila Clementino, São Paulo

04023-062, Brazil
}

(c) The Author(s). 2018 Open Access This article is distributed under the terms of the Creative Commons Attribution 4.0 International License (http://creativecommons.org/licenses/by/4.0/), which permits unrestricted use, distribution, and reproduction in any medium, provided you give appropriate credit to the original author(s) and the source, provide a link to the Creative Commons license, and indicate if changes were made. The Creative Commons Public Domain Dedication waiver (http://creativecommons.org/publicdomain/zero/1.0/) applies to the data made available in this article, unless otherwise stated. 


\section{Background}

Vitamin D is a prohormone associated with improved bone metabolism and strengthens the immune, respiratory, endocrine and cardiovascular systems [1]. The maintenance of blood concentrations depends predominantly on exposure to sunlight (conversion of cutaneous 7-dehydrocholesterol caused by exposure to ultraviolet $\mathrm{B}$ rays) and, to a lesser extent, the intake of vitamin $\mathrm{D}$ of either animal-derived (cholecalciferol) or plant-derived (ergocalciferol) food sources. Ethnicity, latitude, season, sunscreen and body mass index also influence vitamin D concentrations [2].

The 25-hydroxyvitamin-D [25(OH)D] and 1,25-dihydroxyvitamin-D $\left[1.25(\mathrm{OH})_{2} \mathrm{D}\right]$ can be measured. However, serum concentrations of $25(\mathrm{OH}) \mathrm{D}$ are used both as D2 and D3 to evaluate the nutritional state of patients regarding vitamin $\mathrm{D}$ levels. Calcitriol $\left[1.25(\mathrm{OH})_{2} \mathrm{D}\right]$ is the active form, but its half-life is very short and limits patient blood concentration measurement. Vitamin D deficiency can modify bone metabolism markers such as parathyroid hormone, calcium, phosphor and alkaline phosphatase [1, 2].

The 25(OH)D cutoff points currently in use for the general population are $>30 \mathrm{ng} / \mathrm{mL}, 20$ to $30 \mathrm{ng} / \mathrm{mL}$ and $<20 \mathrm{ng} / \mathrm{dL}$ for sufficiency, insufficiency, and deficiency, respectively, and are based on bone outcomes [3]. Recommended levels are higher than $30 \mathrm{ng} / \mathrm{mL}$ for specific groups, such as pregnant women.

Insufficient $25(\mathrm{OH}) \mathrm{D}$ levels are a global public health issue, and pregnant women are a significant at-risk group. More than half of pregnant women evidence $25(\mathrm{OH}) \mathrm{D}$ concentrations comparable to vitamin D insufficiency [4]. A fetus relies exclusively on the mother's $25(\mathrm{OH}) \mathrm{D}$ concentrations, which affect the placental transfer of calcium and phosphorus, as well as hormonal and immunological balance, all of which are fundamental processes for bone development and fetoplacental integrity [5].

Observational studies suggest correlation between low concentrations of $25(\mathrm{OH}) \mathrm{D}$ (25 hydroxyvitamin $\mathrm{D})$ during pregnancy and a higher risk of complications for the mother, such as pre-eclampsia, gestational diabetes, and bacterial vaginosis, as well as complications for the newborn [6, 7], such as intrauterine growth restriction [8], a higher risk of developing allergies [7] and obesity over the long-term [9].

Some international scientific organizations recommend that pregnant women take supplemental doses of vitamin $\mathrm{D}$, ranging from 600 to 1,000 UI daily doses [10-12]. However, the World Health Organization has not universally adopted this practice [13]. The Brazilian Department of Health also does not recommend routine tests for $25(\mathrm{OH}) \mathrm{D}$ serum concentrations during prenatal care, nor vitamin D supplements for pregnant women.
Some studies evaluated 25(OH)D concentrations in Brazilian pregnant women $[10,11,14]$. However, no studies have been published on women who have prematurely given birth with a gestational age of fewer than 32 weeks.

This study aims to describe $25(\mathrm{OH}) \mathrm{D}$, parathyroid hormone, calcium, phosphorus and alkaline phosphatase plasma concentrations of women who have delivered preterm (<32 weeks) compared to women with full-term pregnancy deliveries, as well as to compare the $25(\mathrm{OH}) \mathrm{D}$ concentrations in mother with those of their newborn infants in both groups.

\section{Methods \\ Study design}

This cross-sectional study was conducted between March 2016 and May 2017 at the Municipal Hospital of São Bernardo do Campo University, São Paulo, Brazil (latitude: $23^{\circ} 41^{\prime} 38^{\prime \prime} \mathrm{S}$ ) with a convenience sample of 66 mothers who had delivered preterm and their newborns (PTNB, < 32 weeks), and 92 mothers full-term pregnancy deliveries and their newborns (FTNB group, 37 to $416 / 7$ weeks), who were adequate for gestational age and with a birth weight $>2500 \mathrm{~g}$. The full-term birth group was included during the spring and summer months of the Southern Hemisphere (September 2016 and March 2017).

Mothers with kidney disease, rheumatic disease, diabetes mellitus type 1 , acquired immune deficiency syndrome (AIDS), and those using immunosuppressants (such as corticosteroids) were excluded. Newborns with significant malformations, genetic disorders, and neonatal hypoxia were also excluded.

The Research Ethics Committee of the ABC Faculty of Medicine approved the project under opinion $\mathrm{N}^{\circ}$ 1.060 .653 , dated 13/05/2015. Mothers included in the study agreed to the procedures of the research and signed the informed consent form.

\section{Data collected \\ Mother's health and prenatal care}

Standardized questionnaires were applied to the mothers, which included questions about their socioeconomic conditions, education, habits (tobacco and alcohol use, medications), pre-existing conditions and obstetric disease (pre-existing pre-pregnancy conditions or those developed during pregnancy), use of vitamin or mineral supplements (iron, folic acid, vitamin D and multivitamins), skin color (white, mixed ethnicity or black), exposure to sunlight, and the regular use of sunscreen.

Their prenatal cards were reviewed for laboratory tests, ultrasounds, date of mothers' last menstrual period, and the anthropocentric measurements of the fetus during the obstetric monitoring of pregnancy. Pre-pregnancy body mass index (BMI) and weekly weight gain adequacy 
during pregnancy were based on weight and height measurements $\left(\mathrm{kg} / \mathrm{m}^{2}\right)$ [15].

\section{Newborn data}

Information about the child's weight, length, and head circumference was retrieved within the first $24 \mathrm{~h}$ of life. The gestational age was preferably calculated according to the date of the mothers' last menstrual period, failing which it was based on the data from the ultrasound taken during the first trimester and, ultimately, according to clinical evaluation of the newborn [16]. The newborns were classified as small, adequate and large for their gestational age using INTERGROWTH-21st standards as a reference [17].

\section{Laboratory tests}

Blood samples were collected from the mothers on delivery at the obstetrics center. Ten (10) $\mathrm{mL}$ of the mothers' blood were drawn by arm venipuncture and, in the case of the newborns, from the umbilical cord vein. The material was immediately placed in tubes (one dry and one with EDTA) and submitted to the hospital's clinical analysis laboratory, where they were centrifuged and then transported under refrigeration to the $A B C$ School of Medicine to measure the level of $25(\mathrm{OH}) \mathrm{D}$ (electrochemiluminescence, Roche, Mannheim, Germany), intact parathyroid hormone (PTH; electrochemiluminescence, Roche, Mannheim, Germany), calcium, phosphorus, and alkaline phosphatase (colorimetric method). In the case of mothers, 25(OH)D concentrations $<30 \mathrm{ng} /$ $\mathrm{mL}$ were considered insufficient, and PTH $>65 \mathrm{pg} / \mathrm{mL}$ were deemed to be elevated [3].

All calculations followed the best clinical practice. The mean of $19.9 \mathrm{ng} / \mathrm{mL}$ (SD: $0.948 \mathrm{ng} / \mathrm{mL}$ and an intra-control $\mathrm{CV}$ of $4.8 \%$ ) was the referred reproducible value to measure the $25(\mathrm{OH}) \mathrm{D}$. For the same parameter, the intermediate precision was $19.9 \mathrm{ng} / \mathrm{mL}$ (SD: $1.23 \mathrm{ng} /$ $\mathrm{mL}$ and an intra-control $\mathrm{CV}$ of $6.2 \%$ ). For $\mathrm{PTH}$, an average of $54.6 \mathrm{pg} / \mathrm{mL}$ was referred for repeatability with SD: $0.657 \mathrm{pg} / \mathrm{mL}$ and an intra-control CV of $1.2 \%$. The mean intermediate precision was $54.6 \mathrm{pg} / \mathrm{mL}$ with a DP of $1.11 \mathrm{pg} / \mathrm{mL}$ and $\mathrm{CV}$ of $2.0 \%$.

\section{Data analysis}

A spreadsheet was drafted on Microsoft Excel ${ }^{\circ}$ with data on identification, general characteristics, data from the questionnaires regarding mothers and newborns, anthropometric data and the results of the laboratory tests. The spreadsheet was revised, consolidated and analyzed using the statistical package SPSS $25.0\left(\mathrm{IBM}^{\circ}\right)$ to display the results.

The categorical variables were compared using the Chi-squared test in the bivariate analysis. Continuous analyses were tested for their normality through their distribution in histograms and a kurtosis evaluation. Since they were parametric, they were shown according to their means (standard deviation) and compared according to Student's t-test for independent variables. Pearson's coefficient was adopted to analyze correlations.

The comparison of the clinical and laboratory variables evidenced that the seasons during which the mothers were pregnant and exposure to sunlight differed between the groups. Thus, a stratified analysis of the frequency of $25(\mathrm{OH}) \mathrm{D}$ insufficiencies during spring and summer was conducted with multivariate analysis, using a logistic regression according to the Enter mode method to assess the adjusted effect of prematurity on the odds ratios of 25(OH)D insufficiency.

Pearson's correlation assessed the correlation between mothers' and newborns' 25(OH)D concentrations in both groups assessed by Pearson's correlation. The significance level adopted was $5 \%$. The sample employed in the study proved sufficient to detect a difference of $5 \mathrm{ng} / \mathrm{mL} 25(\mathrm{OH}) \mathrm{D}$ between the groups [18] by adopting bidirectional $\alpha=0.05$ and $\beta=0.20$.

\section{Results}

Table 1 shows the general characteristics of the mothers and newborns in both the preterm and full-term birth groups. There was no difference between the groups regarding mother's age, ethnicity, number of pregnancies, sunscreen use, alcohol use, tobacco use, pre-pregnancy body mass index, or use of vitamin $\mathrm{D}$ or iron supplements. Mothers in the PTNB group had a lower frequency of folic acid supplementation [Yes: 46 (70.8\%) vs $92(87.6 \%) ; p=0.038]$, prenatal care $[<6$ visits: 54 $(81.8 \%)$ vs $20(21.7 \%) ; p<0.001)$ and regular exposure to sunlight [Yes: 5 (7.6\%) vs 54 (58.7\%); $p<0.001$ ].

The main complications associated with premature births were pregnancy-related hypertensive disorders (27) $(40.9 \% ; p<0.001)$. Among women with pregnancyrelated hypertensive disorders, $21(77.8 \%)$ were taking methyldopa.

The mean of gestational age and birth weight in newborns of the PTNB group were $29.8 \pm 2.4$ weeks $(p<0.001)$ and $1250 \pm 354.6 \mathrm{~g}(p<0.001)$, respectively. In this group, 14 (21.2\%) were small for their gestational age (Table 1). All these variables show a statistically significant difference concerning the FTNB group (Table 1).

The mothers in the PTNB group had lower mean values $(21.7 \pm 10.8 \mathrm{ng} / \mathrm{mL}$ vs. $26.2 \pm 9.8 \mathrm{ng} / \mathrm{mL}, p=$ $0.011)$ and higher percentage of $25(\mathrm{OH}) \mathrm{D}$ insufficiency and deficiency when compared with the FTNB group $(p=0.018)$ (Table 2). Logistic regression showed that mothers who had delivered preterm babies were three times more likely to have insufficient $25(\mathrm{OH}) \mathrm{D}(\mathrm{OR}=$ 2.993; 95\%CI 1.02-8.74) (Table 3). 
Table 1 Description of the general characteristics of the mothers, preterm newborns (PTNB) and full-term newborns (FTNB)

\begin{tabular}{|c|c|c|c|c|}
\hline \multirow[t]{2}{*}{ Variables } & & \multirow{2}{*}{$\begin{array}{l}\text { PTNB Group } \\
N=66\end{array}$} & \multirow{2}{*}{$\begin{array}{l}\text { FTNB Group } \\
N=92\end{array}$} & \multirow[t]{2}{*}{$p$-value } \\
\hline & & & & \\
\hline \multicolumn{5}{|l|}{ Characteristics of the mothers } \\
\hline Age $(n=158)$ & Years & $26.0 \pm 7.3$ & $26.03 \pm 6.8$ & $0.987^{\mathrm{a}}$ \\
\hline \multirow[t]{3}{*}{ Ethnicity $(n=158)$} & White & $18(27.3 \%)$ & $35(38.0 \%)$ & $0.151^{b}$ \\
\hline & Black & $6(9.1 \%)$ & $3(3.3 \%)$ & \\
\hline & Mixed ethnicity & $42(63.6 \%)$ & $54(58.7 \%)$ & \\
\hline \multirow[t]{3}{*}{ Schooling $(n=150)$} & $<4$ years & $5(8.5 \%)$ & $2(2.2 \%)$ & $0.194^{b}$ \\
\hline & 4 to 8 years & $50(84.7 \%)$ & $81(89.0 \%)$ & \\
\hline & $>8$ years & $4(6.8 \%)$ & $8(8.8 \%)$ & \\
\hline Number of pregnancies $(n=158)$ & Number & $2.2 \pm 1.5$ & $2.3 \pm 1.5$ & $0.761^{\mathrm{a}}$ \\
\hline Alcohol use $(n=158)$ & Yes & $5(7.6 \%)$ & $4(4.3 \%)$ & $0.492^{b}$ \\
\hline Tobacco use $(n=158)$ & Yes & $13(19.7 \%)$ & $10(10.9 \%)$ & $0.169^{b}$ \\
\hline Vitamin D Suplementation $(n=158)$ & Yes & $6(9.1 \%)$ & $5(5.4 \%)$ & $0.528^{b}$ \\
\hline Folic Acid $(n=158)$ & Yes & $46(70.8 \%)$ & $92(87.6 \%)$ & $0.038^{b}$ \\
\hline Iron $(n=158)$ & Yes & $50(75.8 \%)$ & $76(82.6 \%)$ & $0.320^{b}$ \\
\hline Frequent use of sunscreen $(n=158)$ & Yes & $9(13.6 \%)$ & $23(25.0 \%)$ & $0.108^{b}$ \\
\hline Regular exposure to sunlight $(n=158)$ & Yes & $5(7.6 \%)$ & $54(58.7 \%)$ & $<0.001^{\mathrm{b}}$ \\
\hline \multirow[t]{3}{*}{ Pregnancy-induced illness $(n=158)$} & Hypertension & 27 (40.9\%) & $14(15.2 \%)$ & $<0.001^{\mathrm{b}}$ \\
\hline & Gestational diabetes & $3(4.5 \%)$ & 2 (2.2\%) & $0.650^{\mathrm{b}}$ \\
\hline & Urinary tract infection & $14(21.2 \%)$ & $32(34.8 \%)$ & $0.077^{b}$ \\
\hline \multirow[t]{3}{*}{ Prenatal care $(n=158)$} & Yes (> 6 check-ups) & $12(18.2 \%)$ & $71(78.3 \%)$ & $<0.001^{\mathrm{b}}$ \\
\hline & Yes $(<6$ check-ups) & $42(63.6 \%)$ & $16(17.4 \%)$ & \\
\hline & No (no check-ups) & $12(18.2 \%)$ & $4(4.3 \%)$ & \\
\hline \multirow[t]{4}{*}{ Pre-pregnancy BMI $(n=116)$} & $>30 \mathrm{~kg} / \mathrm{m}^{2}$ & $6(19.4 \%)$ & $19(22.4 \%)$ & $0.905^{\mathrm{b}}$ \\
\hline & 25 to $29.9 \mathrm{~kg} / \mathrm{m}^{2}$ & $8(25.8 \%)$ & $22(25.9 \%)$ & \\
\hline & 18.5 to $24.9 \mathrm{~kg} / \mathrm{m}^{2}$ & $16(51.6 \%)$ & $39(45.9 \%)$ & \\
\hline & $<18.5 \mathrm{~kg} / \mathrm{m}^{2}$ & $1(3.2 \%)$ & $5(5.9 \%)$ & \\
\hline \multirow[t]{3}{*}{ Pregnancy weight gain } & High & $18(58.1 \%)$ & $55(65.5 \%)$ & $0.720^{\mathrm{b}}$ \\
\hline & Adequate & $7(22.4 \%)$ & $14(16.7 \%)$ & \\
\hline & Low & $6(19.4 \%)$ & 15 (17.9\%) & \\
\hline \multirow[t]{4}{*}{ Season $(n=158)$} & Spring & $14(21.2 \%)$ & $48(52.2 \%)$ & $<0.001^{\mathrm{b}}$ \\
\hline & Summer & $24(36.4 \%)$ & $44(47.8 \%)$ & \\
\hline & Fall & $16(24.2 \%)$ & $0(0.0 \%)$ & \\
\hline & Winter & $12(18.2 \%)$ & $0(0.0 \%)$ & \\
\hline \multicolumn{5}{|l|}{ Newborn Characteristics } \\
\hline Gender $(n=158)$ & Male & $35(53.0 \%)$ & $50(54.3 \%)$ & $0.727^{b}$ \\
\hline Type of birth $(n=158)$ & Vaginal & $17(25.8 \%)$ & 48 (52.2\%) & $0.001^{b}$ \\
\hline Gestational Age $(n=158)$ & Weeks & $29.8 \pm 2.4$ & $39.3 \pm 1.2$ & $<0.001^{a}$ \\
\hline Birth weight $(n=158)$ & Grams & $1250 \pm 354.6$ & $3317 \pm 449.4$ & $<0.001^{a}$ \\
\hline \multirow[t]{3}{*}{ Size for gestational age $(n=158)$} & Small for GA & $14(21.2 \%)$ & $0.0(0.0 \%)$ & $<0.001^{\mathrm{b}}$ \\
\hline & Adequate for GA & 47 (71.2\%) & $83(90.2 \%)$ & \\
\hline & Large for GA & $5(7.6 \%)$ & $9(9.8 \%)$ & \\
\hline
\end{tabular}

\footnotetext{
${ }^{a}$ Average and standard deviation. Level of significance of Student's t-test
}

${ }^{b}$ Number (percentage). Level of significance of the chi-squared test 
Table 2 Description of general characteristics of preterm newborns (PTNB) and full-term newborns (FTNB) included in this study

\begin{tabular}{|c|c|c|c|c|}
\hline Variables & & $\begin{array}{l}\text { PTNB Group } \\
(n=66)\end{array}$ & $\begin{array}{l}\text { FTNB Group } \\
(n=92)\end{array}$ & $p$-value \\
\hline \multicolumn{5}{|l|}{ Mother } \\
\hline $25(\mathrm{OH}) \mathrm{D}(n=144)$ & $\mathrm{ng} / \mathrm{mL}$ & $21.7 \pm 10.8$ & $26.2 \pm 9.8$ & $0.011^{\mathrm{a}}$ \\
\hline Deficiency & n (\%) & $27(43.5 \%)$ & $23(28.0 \%)$ & \multirow[t]{3}{*}{$0.018^{b}$} \\
\hline Insufficiency & n (\%) & $25(40.3 \%)$ & 29 (35.4\%) & \\
\hline Sufficiency & n (\%) & $10(16.1 \%)$ & $30(36.6 \%)$ & \\
\hline Parathyroid hormone $(n=121)$ & $\mathrm{pg} / \mathrm{mL}$ & $50.1 \pm 40.7$ & $51.1 \pm 37.6$ & $0.890^{\mathrm{a}}$ \\
\hline Calcium $(n=145)$ & $\mathrm{mg} / \mathrm{dL}$ & $7.8 \pm 1.2$ & $8.7 \pm 1.0$ & $<0.001^{\mathrm{a}}$ \\
\hline Phosphorus $(n=144)$ & $\mathrm{mg} / \mathrm{dL}$ & $3.4 \pm 1.5$ & $3.3 \pm 0.9$ & $0.718^{a}$ \\
\hline Alkaline phosphatase $(n=145)$ & $\mathrm{U} / \mathrm{L}$ & $178.0 \pm 81.6$ & $269.1 \pm 77.4$ & $<0.001^{\mathrm{a}}$ \\
\hline \multicolumn{5}{|l|}{ Umbilical cord } \\
\hline $25(\mathrm{OH}) \mathrm{D}(n=140)$ & $\mathrm{ng} / \mathrm{mL}$ & $25.9 \pm 13.9$ & $31.9 \pm 12.3$ & $0.009^{\mathrm{a}}$ \\
\hline Deficiency & n (\%) & $25(41.7 \%)$ & $17(21.3 \%)$ & \multirow[t]{3}{*}{$0.033^{b}$} \\
\hline Insufficiency & n (\%) & $13(21.7 \%)$ & $24(30.0 \%)$ & \\
\hline Sufficiency & n (\%) & $22(36.7 \%)$ & $39(48.4 \%)$ & \\
\hline Calcium $(n=139)$ & $\mathrm{mg} / \mathrm{dL}$ & $9.3 \pm 1.1$ & $10.2 \pm 1.0$ & $<0.001^{a}$ \\
\hline Phosphorus $(n=138)$ & $\mathrm{mg} / \mathrm{dL}$ & $5.9 \pm 2.1$ & $5.0 \pm 1.2$ & $0.002^{\mathrm{a}}$ \\
\hline Alkaline phosphatase $(n=140)$ & $U / L$ & $363.3 \pm 185.1$ & $324.1 \pm 344.4$ & $0.431^{a}$ \\
\hline
\end{tabular}

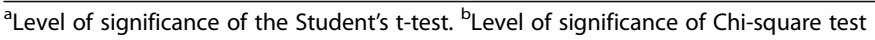

No correlation was observed between $25(\mathrm{OH}) \mathrm{D}$ insufficiency and pregnancy complications (PIH, DM, and $m$ UTI) nor habits during pregnancy (tobacco use, alcohol use, and iron, folic acid, and vitamin D supplementation) among women in the PTNB group (data not shown).

The 25(OH)D levels of newborns were also lower in the PTNB group compared to the FTNB group (25.9 \pm $13.9 \mathrm{ng} / \mathrm{dL}$ vs. $31.9 \pm 12.3 \mathrm{ng} / \mathrm{dL} ; p=0.009$ ) (Table 2 ). Vitamin D insufficiency and deficiency was higher in the PTNB group compared to the FTNB group $(p=0.033)$ (Table 2).

There was a directly proportional correlation between $25(\mathrm{OH}) \mathrm{D}$ concentrations of mother and newborn umbilical cord in the PTNB group $(r=0.596 ; p<0.001)$ and the FTNB group $(r=0.765 ; p<0.001)$ (Fig. 1). An inverse correlation was found between $\mathrm{PTH}$ and $25(\mathrm{OH}) \mathrm{D}$ concentrations in all mothers $(r=-0.230 ; p=0.012)$. However, no statistically significant difference was observed between the groups concerning PTH (23.2\% vs. $12.3 \% ; p=0.090$ ).

Table 3 Odds ratio of $25(\mathrm{OH}) \mathrm{D}$ insufficiency in the mothers included in this study

\begin{tabular}{llll}
\hline Variable & Beta & Confidence Interval 95\% & $p$-value \\
\hline Season (Spring/Summer) & 0.831 & 0.21 to 3.30 & 0.793 \\
Exposure to sunlight (no) & 1.158 & 0.48 to 2.74 & 0.739 \\
Prematurity & 2.993 & 1.02 to 8.74 & 0.045 \\
\hline
\end{tabular}

With regard to the other bone metabolism-related markers, we found that the PTNB group had lower levels of calcium $(7.8 \pm 1.2 \mathrm{mg} / \mathrm{dL}$ vs. $8.7 \pm 1.0 \mathrm{mg} / \mathrm{dL}$; $p<0.001)$ and alkaline phosphatase $(178.0 \pm 81.6 \mathrm{U} / \mathrm{L}$ vs. $269.1 \pm 77.4 \mathrm{U} / \mathrm{L} ; p<0.001)$ when compared to the FTNB group (Table 2).

\section{Discussion}

This study found that mothers who had given birth prematurely had a lower concentration of $25(\mathrm{OH}) \mathrm{D}$ compared to those who had given birth the end of their full term. The 25(OH)D levels of the newborns, in both groups, correlated with those of the mothers. However, this correlation was more significant in the FTNB group.

Vitamin D sufficiency ( $>30 \mathrm{ng} / \mathrm{mL}$ ) was found in $20.8 \%$ of mothers and $42.3 \%$ of newborns. Some studies in Brazil describe the 25(OH)D concentrations during pregnancy $[10,11,14]$. The prevalence of insufficiency/ deficiency evidenced by them (range: $44.1 \%$ to $58.9 \%$ ) was lower than this study, taking to account term birth (63.4\%) and preterm birth (83.9\%). Lower exposure to sunlight, no intake of supplements, low socioeconomic level, and African descent are considered at risk for insufficiency [4]. There are currently no data available for Brazil regarding preterm newborns and their mothers.

The cross-sectional study model does not allow the attribution of a cause and effect relationship. Therefore, we cannot infer whether a vitamin D deficiency was the cause of preterm birth. However, a meta-analysis that 

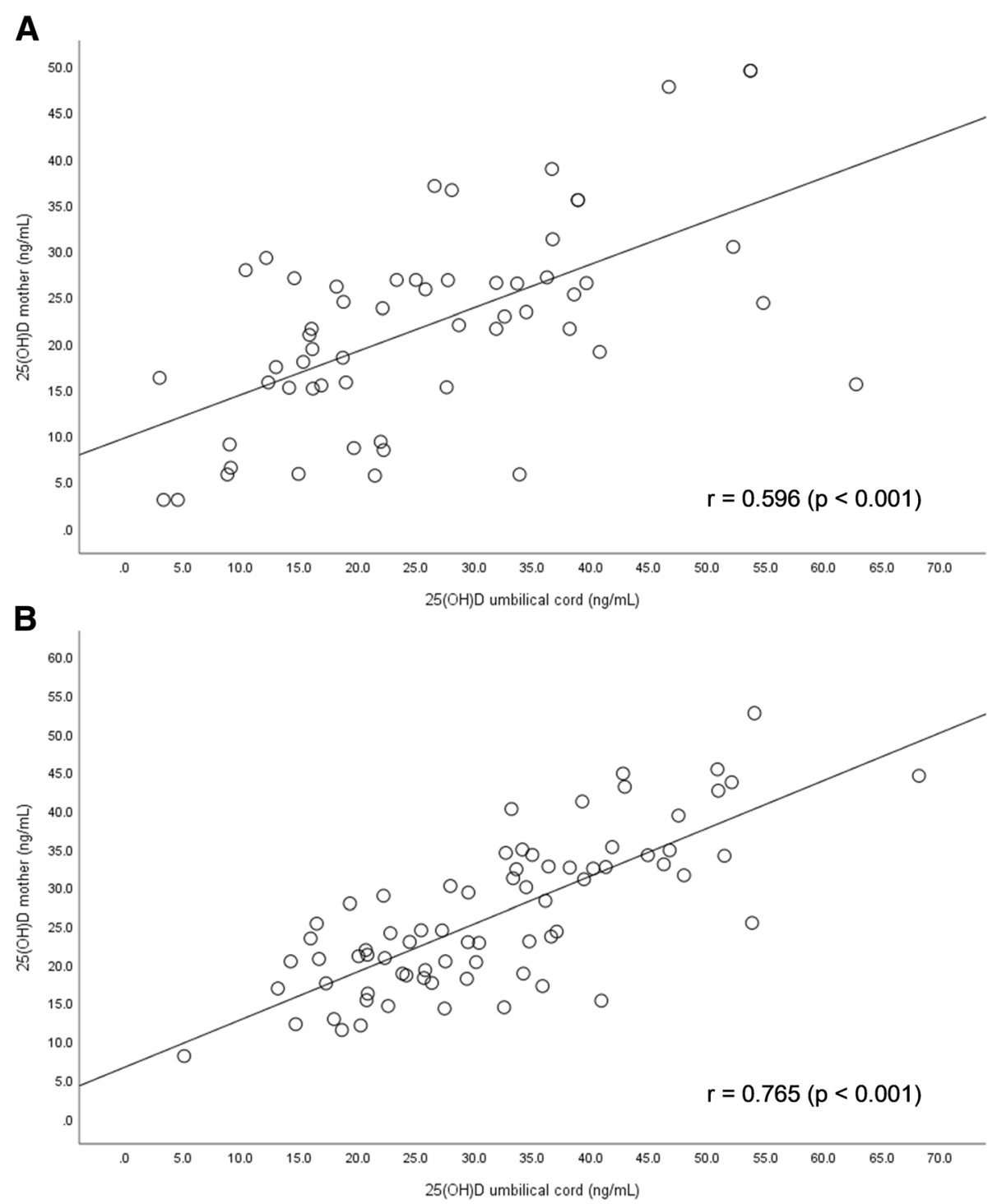

Fig. 1 Correlation of 25(OH)D concentrations in the mothers and umbilical cords in the PTNB group (a) and FTNB group (b). Level of significance of Pearson's correlation test

included only longitudinal studies confirmed that mothers with $25(\mathrm{OH}) \mathrm{D}$ concentrations below $30 \mathrm{ng} / \mathrm{mL}$ were $83 \%$ more likely to give birth prematurely [19].

The transport and metabolism of vitamin D of mothers and newborns have several particularities that should be considered when interpreting the results of this study. First, vitamin D is transported in the blood by the vitamin D-binding protein (DBP) (90\%) and albumin $(10 \%)$, and only $0.03 \%$ of it is unbound. The liver increases its DBP production, and lower levels of circulating albumin [20] are observed during pregnancy. The method adopted in this study to analyze $25(\mathrm{OH}) \mathrm{D}$ only allows for the evaluation of the DBP-bound percentage.

Secondly, the production of epimers related to the metabolism of vitamin D [ex: 3-epi25(OH)D3 and 3-epi-1.25 $(\mathrm{OH})_{2} \mathrm{D} 3$ ] rise during pregnancy, as well as in infants during the first 3 months of life [21]. This elevation is more significant in preterm newborns [21]. Until recently, it was not possible to measure the level of epimers in the blood or understand their function. However, recent studies have shown their affinity with $25(\mathrm{OH}) \mathrm{D}$ receptors, as well as $1,25(\mathrm{OH}) \mathrm{D}$ receptors, and also inhibit the production of PTH. Therefore, they play a role in the metabolism of vitamin D situations, such as prematurity [22].

Studies have shown the benefits of taking vitamin D supplements to reduce the probability of preterm birth [6]. In 2016, Wagner et al. observed a 60\% decline in premature births in U.S. mothers with $25(\mathrm{OH}) \mathrm{D}$ concentrations above $40 \mathrm{ng} / \mathrm{dL}$. The authors concluded that a 
prescribed supplementation of at least $4000 \mathrm{UI} /$ day was required [23] to achieve these levels.

PTH concentrations are influenced by dietary factors (calcium intake), 1,25(OH)D levels and peptide levels related to PTH (PHTrP) produced in the parathyroid of the fetus and the placental tissue, and that step up vitamin D synthesis. While no difference in the mean PTH levels was observed between the groups, inverse correlation was found between PTH and 25(OH)D concentrations in all mothers. From a physiological perspective, the opposite was expected, as PTH levels tend to increase in the third trimester of pregnancy [24, 25]. A study that assessed the development of PTH concentrations in pregnant adolescents found an increase of $16.3 \mathrm{pg} / \mathrm{mL}$ between the 26th week of pregnancy and the moment of birth [26].

A difference between the levels of calcium, phosphorus and alkaline phosphatase in the blood was found between mothers who delivered preterm babies and those with full-term pregnancy deliveries. However, none of these markers correlated significantly with the $25(\mathrm{OH}) \mathrm{D}$ concentrations found in newborns and their mothers, suggesting that the factors involved in this alteration may be more related to maternal hemodilution than to vitamin $\mathrm{D}$ [27].

The $25(\mathrm{OH}) \mathrm{D}$ concentrations found in the mothers were lower than in their newborns and correlated with those of the newborns in both groups. In the meta-analysis published by Saraf et al., 2016 [4], forty studies confirmed a correlation between $25(\mathrm{OH}) \mathrm{D}$ concentrations in mothers and the umbilical cords of newborns, and the correlation coefficient ranged from 0.42 to 0.96 . Only three studies found higher levels in the umbilical cords than in the mothers. According to the findings of this study, the closer a mother is to the end of her full-term pregnancy, the stronger the correlations of vitamin $\mathrm{D}$ levels between mother and newborn will be. All the three studies that found higher levels in newborns showed a higher prevalence of vitamin D insufficiency/deficiency. These findings suggest that gestational age and vitamin D sufficiency interact with the flow of vitamin D from mother to newborn.

Given the particularities of vitamin D metabolism during pregnancy, the lack of well-established cut-off points, and the limited number of studies evaluating the short and long-term safety of supplementation for mothers and their children, it is not currently advisable to universally recommend vitamin D supplementation to pregnant women. The identification of at-risk expecting mothers and the measurement of other vitamin D metabolism markers can provide clues regarding which pregnant women indeed evidence low levels and should take supplements.
Recently, a randomized, double-blind, placebo-controlled trial in Bangladesh assessed the effects of weekly prenatal vitamin D supplementation during pregnancy and postpartum. The authors did not find improvement in fetal or infant growth until 1 year of age [28].

To date, this is the first study conducted in Brazil that has evaluated 25(OH)D concentrations in a group of mothers who gave birth before the 32nd week of pregnancy and their newborns.

The lack of an evaluation of dietary factors, especially mothers' calcium intake, the difficulty of collecting part of the prenatal care data and accurately establishing the cause of preterm delivery can all be considered limitations of this study.

\section{Conclusions}

In conclusion, mothers who had delivered preterm babies (less than 32 weeks) and their premature newborns had lower 25(OH)D concentrations compared to women with full-term pregnancy deliveries. In both groups, $25(\mathrm{OH}) \mathrm{D}$ concentrations of the mothers correlated directly with those of the newborns, and this correlation was higher in the full-term birth group. Nevertheless, the recommended universal vitamin D supplementation in pregnant women to curb the risk of preterm birth is still incipient. More studies are required to clarify the particularities of vitamin D metabolism further and define the adequate $25(\mathrm{OH}) \mathrm{D}$ concentrations throughout pregnancy.

\section{Abbreviations}

25(OH)D: Vitamin D; FTNB: Full-term newborn; PTH: Intact parathyroid hormone; PTNB: Preterm newborn

\section{Acknowledgments}

We are grateful to the multidisciplinary team of Municipal University Hospital of São Bernardo do Campo for their support to the implementation of the Project, and the clinical analysis laboratory of the ABC School of Medicine for their analyses.

\section{Funding}

Financial Support: Foundation for Research Support of the State of São Paulo (FAPESP). Process number 2015/15399-1. (Certificate of presentation for Ethical Appreciation: 44213315.1.0000.0082).

\section{Availability of data and materials}

The datasets generated during and/or analyzed during the current study are available from the corresponding author on reasonable request.

\section{Authors' contributions}

MSK, FISS, and ROS: contributed with the outline, design, and data acquisition, analysis and interpretation. FRC and FAK contributed with data acquisition, analysis, and interpretation. All authors approved the final version of the manuscript.

\section{Ethics approval and consent to participate}

The Research Ethics Committee of the ABC Faculty of Medicine approved the project under opinion $N^{\circ} 1.060 .653$, dated 13/05/2015. Mothers included in the study agreed to the procedures of the research and signed the informed consent form. 


\section{Consent for publication}

Not applicable.

\section{Competing interests}

The authors declare that they have co competing interests.

\section{Publisher's Note}

Springer Nature remains neutral with regard to jurisdictional claims in published maps and institutional affiliations.

Received: 5 July 2018 Accepted: 5 October 2018

Published online: 22 October 2018

\section{References}

1. Afzal S, Brøndum-Jacobsen P, Bojesen SE, Nordestgaard BG. Vitamin D concentration, obesity, and risk of diabetes: a Mendelian randomization study. Lancet Diabetes Endocrinol. 2014;2:298-306.

2. van Schoor N, Lips P. Global overview of vitamin D status. Endocrinol Metab Clin N Am. 2017:46:845-70.

3. Gel-H F, Bouillon R, Clarke B, Chakhtoura M, Cooper C, McClung M, Singh RJ. Serum 25-Hydroxyvitamin D levels: variability, knowledge gaps, and the concept of a desirable range. J Bone Miner Res. 2015:30:1119-33.

4. Saraf R, Morton SM, Camargo CA Jr, Grant CC. Global summary of maternal and newborn vitamin D status - a systematic review. Matern Child Nutr. 2016;12:647-68

5. Olmos-Ortiz A, Avila E, Durand-Carbajal M, Díaz L. Regulation of calcitrio biosynthesis and activity: focus on gestational vitamin $D$ deficiency and adverse pregnancy outcomes. Nutrients. 2015;7:443-80.

6. Zhou SS, Tao YH, Huang K, Zhu BB, Tao FB. Vitamin D and risk of preterm birth: up-to-date meta-analysis of randomized controlled trials and observational studies. J Obstet Gynaecol Res. 2017;43:247-56.

7. Amegah AK, Klevor MK, Wagner CL. Maternal vitamin D insufficiency and risk of adverse pregnancy and birth outcomes: a systematic review and meta-analysis of longitudinal studies. PLoS One. 2017;12:e0173605.

8. Tian Y, Holzman C, Siega-Riz AM, Williams MA, Dole N, Enquobahrie DA, Ferre CD. Maternal serum 25-Hydroxyvitamin D concentrations during pregnancy and infant birthweight for gestational age: a three-cohort study. Paediatr Perinat Epidemiol. 2016;30:124-33.

9. Feng $H$, Xun P, Pike K, Wills AK, Chawes BL, Bisgaard H, Cai W, Wan Y, He K. In utero exposure to 25-hydroxyvitamin D and risk of childhood asthma, wheeze, and respiratory tract infections: a meta-analysis of birth cohort studies. J Allergy Clin Immunol. 2017;139:1508-17.

10. Pereira-Santos M, Queiroz-Carvalho G, David-Couto R, Barbosa Dos Santos D, Marlucia Oliveira A. Vitamin D deficiency and associated factors among pregnant women of a sunny city in Northeast of Brazil. Clin Nutr ESPEN. 2018;23:240-4

11. Figueiredo ACC, Cocate PG, Adegboye ARA, Franco-Sena AB, Farias DR, de Castro MBT, et al. Changes in plasma concentrations of 25-hydroxyvitamin D and 1,25-dihydroxyvitamin D during pregnancy: a Brazilian cohort. Eur J Nutr. 2018:57:1059-72

12. Boyle VT, Thorstensen EB, Thompson JMD, McCowan LME, Mitchell EA Godfrey KM, Poston L, Wall CR, Murphy R, Cutfield W, Kenealy T, Kenny LC, Baker PN. The relationship between maternal 25-hydroxyvitamin D status in pregnancy and childhood adiposity and allergy: an observational study. Int J Obes. 2017:41:1755-60.

13. Guideline. Vitamin D supplementation in pregnant women. Geneva: World Health Organization; 2012.

14. Chrisostomo KR, Skare TL, Kulak J Jr, Urbanetz AA, Chrisostomo ER, Nisihara R. The prevalence and clinical associations of hypovitaminosis $D$ in pregnant women from Brazil. Int J Gynaecol Obstet. 2018;143(1):66-70. https://doi.org/ 10.1002/ijgo.12575

15. Institute of Medicine (US) and National Research Council (US) Committee to Reexamine IOM Pregnancy Weight Guidelines. In: Rasmussen KM, Yaktine AL, editors. Weight gain during pregnancy: Reexamining the Guidelines. Washington (DC): National Academies Press (US); 2009

16. Ballard JL, Khoury JC, Wedig K, Wang L, Eilers-Walsman BL, Lipp R. New Ballard score, expanded to include extremely premature infants. J Pediatr. 1991;119:417-23.

17. Villar J, Cheikh Ismail L, Victora CG, Ohuma EO, Bertino E, Altman DG, et al. International fetal and newborn growth consortium for the 21st century (INTERGROWTH-21st). International standards for newborn weight, length, and head circumference by gestational age and sex: the newborn crosssectional study of the INTERGROWTH-21st project. Lancet. 2014:384:857-68.

18. Hurley SB. Outlining the clinical research: an epidemiological approach. 2nd ed. Porto Alegre: Artmed; 2003.

19. Amegah AK, Nsoh M, Ashley-Amegah G, Anaman-Togbor J. What factors influences dietary and non-dietary vitamin D intake among pregnant women in an African population? Nutrition. 2018:50:36-44. https://doi.org/ 10.1016/..nut.2017.11.003

20. Tsuprykov O, Chen X, Hocher CF, Skoblo R, Lianghong Yin, Hocher B. Why should we measure free $25(\mathrm{OH})$ vitamin D? J Steroid Biochem Mol Biol. 2018;180:87-104. https://doi.org/10.1016/j.jsbmb.2017.11.014.

21. Bailey D, Perumal N, Yazdanpanah M, Al Mahmud A, Baqui AH, Adeli K, Roth DE. Maternal-fetal-infant dynamics of the C3-epimer of 25-hydroxyvitamin D. Clin Biochem. 2014;47:816-22.

22. Ooms N, van Daal H, Beijers AM, Gerrits GP, Semmekrot BA, van den Ouweland JM. Time-course analysis of 3-epi-25-hydroxyvitamin D3 shows markedly elevated levels in early life, mainly from vitamin D supplementation in preterm infants. Pediatr Res. 2016;79:647-53.

23. Wagner CL, Baggerly C, McDonnell S, Baggerly KA, French CB, Baggerly L, Hamilton SA, Hollis BW. Post-hoc analysis of vitamin D status and reduced risk of preterm birth in two vitamin D pregnancy cohorts compared with South Carolina March of Dimes 2009-2011 rates. J Steroid Biochem Mol Biol. 2016;155:245-51.

24. McDonnell SL, Baggerly KA, Baggerly CA, Aliano JL, French CB, Baggerly LL, Ebeling MD, Rittenberg CS, Goodier CG, Mateus Niño JF, Wineland RJ, Newman RB, Hollis BW, Wagner CL. Maternal 25(OH)D concentrations $\geq 40$ $\mathrm{ng} / \mathrm{mL}$ associated with $60 \%$ lower preterm birth risk among general obstetrical patients at an urban medical center. PLoS One. 2017;12:e0180483.

25. Wagner CL, Taylor SN, Dawodu A, Johnson DD, Hollis BW. Vitamin D and its role during pregnancy in attaining optimal health of mother and fetus. Nutrients. 2012:4:208-30.

26. Young BE, McNanley TJ, Cooper EM, Mclntyre AW, Witter F, Harris ZL, O'Brien KO. Vitamin D insufficiency is prevalent and vitamin D is inversely associated with parathyroid hormone and calcitriol in pregnant adolescents. Bone Miner Res. 2012;27:177-86.

27. Abrams SA. In utero physiology: role in nutrient delivery and fetal development for calcium, phosphorus, and vitamin D. Am J Clin Nutr. 2007:85:604S-7S

28. Roth DE, Morris SK, Zlotkin S, Gernand AD, Ahmed T, Shanta SS, et al Vitamin D supplementation in pregnancy and lactation and infant growth. $N$ Engl J Med. 2018;379:535-46.
Ready to submit your research? Choose BMC and benefit from:

- fast, convenient online submission

- thorough peer review by experienced researchers in your field

- rapid publication on acceptance

- support for research data, including large and complex data types

- gold Open Access which fosters wider collaboration and increased citations

- maximum visibility for your research: over $100 \mathrm{M}$ website views per year

At $\mathrm{BMC}$, research is always in progress.

Learn more biomedcentral.com/submissions 